\title{
PENGALAMAN PRESEPTOR DALAM MELAKSANAKAN PRECEPTORSHIP DI RUMAH SAKIT SAINT ELISABETH KOTA MEDAN 2018
}

\author{
Maria Pujiastuti \\ STIKes Santa Elisabeth Medan, Indonesia \\ Email: mariapujiastuti123@gmail.com
}

\begin{abstract}
Preceptorship is a teaching and learning method to university students by involving nurses as the role model. The objective of preceptorship program in learning is to build the students' role and responsibility to be professional nurses with wide knowledge. The major aim of this research was to study further preceptor's experience in conducting preceptorship program in the hospitals in Medan. This is a descriptive phenomenological study. Questionnaires with demographic characteristics and guided interviews were used as the research instruments. The data were collected through in-depth interview and by using field-note. Purposive sampling technique was employed to select the participants who met the inclusion criteria. The participants consist of 10 preceptors in Santa Elisabeth Hospital, Medan. The descriptions of the preceptors' experience were analyzed by using Colaizzi approach. The results found out 5 themes reflecting the studied phenomena. The themes were maximally preparing themselves before conducting preceptorship program, the preceptors', responsibilities in conducting counseling process, unpleasant experience during the student counseling, the preceptors' expectation to the corrective process in the preceptorship counseling, and the preceptors are the students' role model during the practice. According to the research results, it is suggested that nursing education is committed to follow the policies, standards, procedures, and regulations set forth in the guidebook, for nursing services to facilitate the preceptor by improving the knowledge of the preceptorship program up to date, and It is also expected that this nursing research can become the evidence-based data for the facility improvement to the future researchers.
\end{abstract}

Keywords: experience, preceptor, preceptorship program

\section{PENDAHULUAN}

Preceptorship merupakan komponen yang vital dalam mempersiapkan mahasiswa keperawatan untuk menuju profesionalitas. Preceptorship memfasilitasi mahasiswa untuk mengembangkan kemampuan kognitif, afektif, dan psikomotorik melalui supervisi, bimbingan, pendampingan dan role model, selain itu juga program preceptorship bertujuan untuk mengenalkan lingkungan kerja yang sebenarnya kepada mahasiswa keperawatan (Smedley, 2008).

Proses kegiatan pembelajaran di lahan klinik sangat dipengaruhi peran dari seorang pembimbing klinik yang biasa disebut preseptor (AIPNI, 2010). Preseptor merupakan seseorang yang ditempatkan di tatanan klinik atau perawat senior yang bekerja di tatanan layanan dan ditetapkan sebagai preseptor. dan harus merupakan seorang ahli atau yang berpengalaman dalam 
memberikan pelatihan dan pengalaman praktik kepada peserta didik. Pelaksanaan pembelajaran klinik terkait erat dengan peran preseptor pada lingkungan klinik yang bertujuan mendorong kemandirian dan kepercayaan diri mahasiswa.

Kemampuan mahasiswa selama pembelajaran di lahan praktik sangat dipengaruhi oleh kemampuan dan pengalaman preseptor. Seorang preseptor harus bertanggung jawab terhadap semua tindakan mahasiswa selama pembelajaran di lahan praktik. Hallin dan Danielson (2008) melakukan penelitian kepada 113 responden mahasiswa keperawatan di Swedia mengenai perubahan pencapaian kompetensi sebelum dan setelah diterapkan model preceptorship, ditemukan hasil yang signifikan bahwa penerapan model preceptorship ini dapat diterapkan di setting pelayanan keperawatan secara umum dan meningkatkan pencapaian kompetensi mahasiswa.

Sejalan dengan Madhavanpraphakaran, Shukri, dan Balachandran (2014) juga menyatakan bahwa dari 76 orang preseptor yang memiliki pengalaman lebih dari 10 tahun di sultan Qaboos University Hospital pada tahun 2011, $87 \%$ responden menyatakan di dalam preceptorship peran preseptor sangat penting untuk meningkatkan kompetensi mahasiswa menjadi perawat profesional dan hasil evaluasi menunjukkan $75 \%$ mahasiswa perawat memiliki perilaku dan komunikasi yang positif, disamping itu peran preseptor yang efektif dapat mempengaruhi kualitas dari sebuah institusi keperawatan.

Banyaknya tuntutan untuk menjadi seorang preseptor yang sempurna menimbulkan beban tersendiri, sebagaimana penelitian Liu, Lei, Mingxia, dan Haobin (2010) yang dilakukan di negara China. Hasil dari penelitian menyebutkan ada banyak hal yang didapatkan seseorang ketika menjalankan peran sebagai preseptor dalam melaksanakan program preceptorship baik itu pengalaman yang menyenangkan maupun pengalaman yang tidak menyenangkan.

Studi pendahuluan yang dilakukan di salah satu rumah sakit swasta di Kota Medan pada saat melakukan praktik perencanaan strategis dalam keperawatan selama 3 bulan dengan mewawancarai seorang preseptor, menyatakan tugas dan tanggung jawab sebagai preseptor tidak dapat terlaksanakan dengan maksimal. Preseptor mengatakan bahwa tidak jarang disalahkan oleh pihak institusi maupun rumah sakit apabila mahasiswa yang praktik tidak terampil dalam melakukan tindakan keperawatan, 
sehingga preseptor dinyatakan tidak mampu membimbing mahasiswa, padahal di lahan praktik, satu orang preseptor harus membimbing lebih dari 10 orang mahasiswa.

Preseptor juga bertanggung jawab membimbing mahasiswa dari 3 program studi yang berbeda sekaligus yaitu D3 Keperawatan, D3 Kebidanan, Ners tahap akademik dan Ners tahap profesi. Berdasarkan hasil studi pendahuluan dan melihat berbagai fenomena terkait pengalaman preseptor dalam melaksanakan program preceptorship. Belum efektifnya program ini membuat peneliti tertarik untuk menggali lebih dalam mengenai pengalaman preseptor dalam melaksanakan program preceptorship di Rumah Sakit yang terdapat di Kota Medan.

Penelitian ini akan dilakukan dengan pendekatan fenomenologi deskriptif sehingga dapat diperoleh gambaran pengalaman secara mendalam terkait fenomena pengalaman preseptor dalam melaksanakan program preceptorship.

\section{METODE}

Jenis penelitian yang dilakukan pada penelitian ini adalah dengan menggunakan pendekatan fenomenologi deskriptif. Lokasi penelitian ini dilakukan di Rumah Sakit Santa Elisabeth Medan. Partisipan dalam kegiatan penelitian ini adalah preseptor yang bekerja di Rumah Sakit Santa Elisabeth Medan. Jumlah partisipan dalam penelitian ini berjumlah 10 orang preseptor karena sudah terjadi saturasi data.

Metode pengumpulan data yang digunakan dalam penelitian ini menggunakan metode wawancara secara mendalam (indepth interview) yang dilakukan oleh peneliti sendiri dengan durasi 50-60 menit. Alat pengumpulan data pada penelitian ini adalah kuesioner data demografi, panduan wawancara, dan field note. Panduan wawancara telah dilakukan content validity index oleh 3 expert.

\section{HASIL DAN PEMBAHASAN}

Penelitian ini berfokus pada pengalaman partisipan menghasilkan 5 tema, antara lain: 1) mempersiapkan diri secara maksimal sebelum melaksanakan program preceptorship, 2) tanggung jawab preseptor dalam melaksanakan proses bimbingan, 3) pengalaman tidak menyenangkan selama membimbing mahasiswa, 4) harapan preseptor terhadap perbaikan proses bimbingan preceptorship, dan 5) preseptor adalah panutan mahasiswa selama praktik.

Mempersiapkan diri secara maksimal sebelum melaksanakan program preceptorship

Hasil penelitian menunjukkan bahwa seluruh partisipan pada penelitian 
ini yaitu preseptor yang bekerja di Rumah Sakit Santa Elisabeth Medan, memiliki persiapan-persiapan tersendiri sebelum melaksanakan program preceptorship pada mahasiswa. Hasil penelitian Phelps (2009) menyatakan bahwa persiapan awal yang efektif dari seorang preseptor dapat menjadi tolak ukur untuk pengembangan proses pembelajaran klinik, sehingga menghasilkan kinerja yang baik yang akan mempengaruhi kompetensi mahasiswa. Hal ini didukung oleh penelitian Tang dan Chiang (2005) yang menyimpulkan bahwa persiapan awal yang efektif dari seorang preseptor akan menghasilkan mahasiswa yang terampil dan kompeten.

Peneliti berasumsi bahwa persiapan yang maksimal dilakukan oleh para preseptor di lahan praktik memiliki pengaruh yang besar terhadap kelancaran proses bimbingan program preceptorship. Preseptor diharapkan mempunyai kemampuan untuk menghadapkan mahasiswa keperawatan kepada pengalaman klinik yang efektif dengan menerapkan metode bimbingan sesuai dengan kebutuhan mahasiswa sehingga dapat meningkatkan perkembangan kepercayaan dan kompetensi mahasiswa. Hal ini nantinya akan berdampak pada terbentuknya sikap profesionalitas mahasiswa dalam meningkatkan kualitas.

\section{Tanggung jawab preseptor dalam melaksanakan proses bimbingan}

Hasil penelitian menunjukkan bahwa 8 dari 10 orang preseptor menyatakan tugas dan tanggung jawab yang diberikan oleh pihak institusi dalam meningkatkan kualitas praktik klinik mahasiswa bukan merupakan pekerjaan yang mudah, namun preseptor tetap selalu berusaha mengupayakan agar seluruh mahasiswa mampu mencapai kompetensi yang sudah ditentukan oleh pihak institusi.

Madhavanpraphakaran, Shukri, dan Balachandran (2014) menyebutkan dari 76 orang perseptor yang memiliki pengalaman lebih dari 10 tahun di Sultan Qaboos University Hospital pada tahun 2011, 87\% responden menyatakan di dalam preceptorship tugas dan tanggung jawab preseptor sangat penting untuk meningkatkan kompetensi mahasiswa menjadi perawat profesional.

Peneliti berasumsi bahwa seorang preseptor juga harus membagi antara tindakan yang menjadi tanggung jawab mahasiswa dan tanggung jawabnya, sehingga dalam melakukan tugasnya seorang perseptor harus benar-benar fokus terhadap peran dan fungsinya.

Dalam pelaksanaan program preceptorship, peran seorang preseptor sangat penting dan merupakan kunci utama keberhasilan mahasiswa maupun perawat baru untuk beradaptasi terhadap 
peran baru dalam layanan kesehatan pasien.

\section{Pengalaman tidak menyenangkan} selama membimbing mahasiswa

Pelaksanaan proses bimbingan preceptorship kepada mahasiswa tidak selalu memberikan pengalaman yang menyenangkan, tetapi ternyata juga terdapat pengalaman yang tidak menyenangkan selama melaksanakan program bimbingan preceptorship.

Hasil penelitian Liu, Lei, Mingxia, dan Haobin (2010) yang dilakukan di negara China menyebutkan ada banyak hal yang didapatkan seseorang ketika menjalankan peran sebagai perseptor, baik itu pengalaman yang menyenangkan maupun pengalaman yang tidak menyenangkan. Pengalaman menyenangkan yaitu lebih dihormati dan disegani oleh teman satu kelompok,, sedangkan pengalaman yang tidak menyenangkan yaitu beban kerja yang berlebih dan stress menghadapi perlakuan mahasiswa dengan pengetahuan yang tidak merata dalam setiap proses bimbingan. Sejalan dengan penelitian studi kualitatif Omansky (2010) yang menyimpulkan tiga tema besar pengalaman yang kurang menyenangkan selama menjadi seorang preseptor yaitu ketidak jelasan akan peran sebagai seorang preceptor, beban kerja yang berlebih, dan pertentangan peran antara menjadi seorang perawat dan sebagai preseptor.

Peneliti berasumsi bahwa pada dasarnya selain lahan praktek, pihak insititusi pendidikan memiliki peran yang besar dalam pencapaian kompetensi mahasiswa. Pihak institusi pendidikan seharusnya memiliki andil yang besar dalam rangka memberi kesempatan mahasiswanya untuk praktek di rumah sakit dan begitu juga dengan lahan praktek sehingga perlu dijalin kerjasama yang baik.

\section{Harapan Preseptor terhadap perbaikan proses bimbingan preceptorship}

Preseptor memiliki banyak harapan kedepannya terkait perbaikan proses bimbingan preceptorship yang selama berjalan di Rumah Sakit. Hasil penelitian menunjukkan bahwa seluruh partisipan penelitian yaitu preseptor yang bekerja di Rumah Sakit Santa Elisabeth Medan memiliki banyak harapan kedepannya terkait perbaikan proses bimbingan preceptorship yang selama ini berjalan di Rumah Sakit. Adapun harapan tersebut meliputi harapan preseptor terhadap mahasiswa, harapan preseptor terhadap rumah sakit, dan harapan preseptor terhadap institusi.

Peneliti berasumsi bahwa harapan yang disampaikan oleh preseptor merupakan harapan untuk perbaikan 
proses bimbingan kepada mahasiswa demi terwujudnya proses bimbingan yang optimal selama melaksanakan program preceptorship sehingga mahasiswa dapat mencapai kompetensi yang telah ditetapkan oleh pihak institusi.

\section{Preseptor adalah panutan bagi mahasiswa selama praktik}

Preceptorship adalah suatu metode pengajaran dan pembelajaran kepada mahasiswa dengan menggunakan perawat sebagai model perannya (role model). Penelitian Mehen dan Clark (2010) mengungkapkan preseptor adalah seorang perawat yang mengajar, memberikan bimbingan, dapat menginspirasi rekannya, menjadi tokoh panutan (role model). Sejalan dengan Minnesota Department of Health (2005), yang menyatakan bahwa seorang preceptor mempunyai 3 peran yaitu sebagai pengasuh, pendidik, dan sebagai panutan.

Barker (2010) menyatakan sebagai role model seorang preseptor dituntut untuk menjadi panutan sebagai seorang perawat yang professional bagi mahasiswa yang memberikan contoh untuk mengaplikasikan skill, mempunyai pengetahuan yang update. Disamping itu mampu mengaplikasikan nilai-nilai keperawatan dan bisa menjalin kerjasama yang profesional dengan profesi medis lainnya (Brathwaite \& Lemonde 2011).

Peneliti berasumsi bahwa peran seorang preseptor di lahan praktik sangat mempengaruhi keberhasilan mahasiswa dalam mencapai kompetensi. Presptor merupaka contoh nyata bagi mahasiswa keperawatan dalam menjalankan perannya sebagai perawat baru yang masih beradaptasi dengan lingkungan kerja nyata di rumah sakit. Preseptor merupakan pengaruh utama dalam pengalaman praktek mahasiswa, sehingga mahasiswa meyakini bahwa preseptor mampu mengari, membimbing dan memotivasi mereka selama melaksankan praktik di rumah sakit.

\section{KESIMPULAN DAN SARAN}

\section{Kesimpulan}

1. Penelitian ini menggunakan pendekatan fenomenologi jenis deskriptif yang bertujuan untuk mendeskripsikan konsep dan makna mendasar dari suatu fenomena yang dialami. Berdasarkan hasil penelitian dan pembahasan dapat disimpulkan bahwa terdapat 5 tema, 10 sub tema dan 28 kategori dari Studi Fenomenologi Pengalaman Preseptor Dalam Melaksanakan Program Preceptorship di Rumah Sakit Kota Medan.

2. Tema-tema yang muncul pada penelitian ini yaitu: 1) 
mempersiapkan diri secara maksimal sebelum melaksanakan program preceptorship, 2) tanggung jawab preseptor dalam melaksanakan proses bimbingan, 3) pengalaman tidak menyenangkan selama membimbing mahasiswa, 4) harapan preseptor terhadap perbaikan proses bimbingan preceptorship, dan 5) preseptor adalah panutan mahasiswa selama praktik.

3. Pengalaman preseptor dalam melaksanakan program preceptorship menunjukkan bahwa preseptor memiliki tugas dan tanggung jawab penting di lahan praktik dalam membentuk mahasiswa keperawatan untuk menjadi seorang perawat profesional dan beradaptasi terhadap peran baru dalam layanan kesehatan pasien. Untuk menunjang peningkatan kualitas mahasiswa harus diikuti dengan peningkatan kualitas preseptor di lapangan serta memerlukan kerjasama antara pihak insitusi Rumah Sakit dengan institusi Pendidikan.

\section{Saran}

\section{Bagi pendidikan keperawatan}

Memiliki komitmen dalam mengikuti kebijakan, standar, prosedur, dan peraturan yang telah ditetapkan di dalam buku panduan dan memutuskan alat ukur penilaian yang

digunakan untuk menilai
performance peserta didik dan
menyampaikan hasil evaluasi
penilaian akhir kepada peserta didik
dan preseptor di lahan praktik.

\section{Bagi pelayanan keperawatan}

Memfasilitasi preseptor dengan meningkatkan ilmu pengetahuan mengenai program preceptorship yang up to date sesuai dengan perkembangan dan kemajuan Ilmu Pengetahuan dan Teknologi dan menunjukkan komitmen terhadap kemitraan antara pihak institusi dan preseptor dalam memfasilitasi aplikasi peserta didik dalam praktek keperawatan.

\section{Bagi penelitian keperawatan}

Penelitian ini dapat dijadikan sebagai data dasar (evidence based) untuk sarana perbaikan bagi peneliti selanjutnya yang ingin melakukan penelitian mengenai preceptorship.

\section{DAFTAR PUSTAKA}

AIPNI. (2010). Kurikulum Berbasis Kompetensi Pendidikan Ners Indonesia. Jakarta: Asosiasi Institusi Penndidikan Ners Indonesia (AIPNI).

Balachandran, Madhavanpraphakaran, Shukri, \&. (2014). Preceptors' perceptions of clinical nursing education. The Journal of Continuing Education in Nursing , 45(1): 28-34. (7p). DOI: $10.3928 / 00220124-$ 20131223-04.

Barker, J. (2010) Evidence-based practice for nurses. London: Sage Publications. 
CNA. (2004). Achieving exelence in profesional practice: a guide for preceptorship and mentoring. Ottawa: Author.

Hallin, K. \& Danielson, E. (2008). Being a personal preceptor for nursing students: registered nurses' experiences before and after introduction of a preceptor model. Journal of Advanced Nursing, 65(1), 161-17. DOI: $10.1111 / \mathrm{j} .1365-$ 2648.2008.04855.

Liu, Lei, Mingxia, \& Haobin (2010). Lived experiences of clinical preceptors: A phenomenological study. Nurse Education Today, Vol 30 : 804-808. DOI: 10.1016/j.nedt.2010.03.004.id

Omansky, G. L. (2010). Staff nurses' experiences as preceptors and mentors: an integrative review. Journal of Nursing Management, (18) 697-703.

DOI: 10.1111/j.1365-2834.2010.01145

Phelps, L. L. (2009). Effective characteristics of clinical Instructors.A Research Paper Submitted to the Graduate School.

Shin, K. R. (2000). The meaning of the clinical learning experience of korean nursing students. Journal of Nursing Education, 39(6), 259.

Smedley, A. M. (2008). Becoming and being a preceptor: a phenomenological study. The Journal of Continuing Education in Nursing, 39(4):185-191, DOI: 10.3928/00220124-20080401-08

Tang, F., Chou, S., \& Chiang, H. (2005). Students' perceptions of effective and ineffective clinical instructors. Journal of Nursing Education, 44(4), 187- 192. 